\title{
In situ studies of calcification and photosynthetic carbon fixation in the coral Montastrea annularis
}

\author{
D. J. BARNes ${ }^{1} \&$ D. L. TAYLOR ${ }^{2}$ \\ ${ }^{1}$ U.W.I.-S.U.N.Y. Marine Laboratory; Discovery Bay, Jamaica, W. I., \\ and \\ 2 Rosenstiel School of Marine and Atmospheric Science, University of Miami; \\ Miami, Florida, USA
}

\begin{abstract}
KURZFASSUNG: In-situ Untersuchungen der Verkalkung und photosynthetischen Kohlenstoffixierung bei der Koralle Montastrea annularis. Das Ausmaß der Verkalkung und photosynthetischen Kohlenstoffixierung wurde bei Individuen von Montastrea annularis in verschiedenen Rifftiefen und unter spezifischen Lichtbedingungen mittels der Radioisotope ${ }^{45} \mathrm{Ca}$ und ${ }^{14} \mathrm{C}$ bestimmt. Die Lichtintensität beeinflußt über die photosynthetische Tätigkeit der symbiotischen Algen vor allem die Geschwindigkeit der Verkalkung und zudem sehr wahrscheinlich die gesamte Wuchsform der Kolonie. Im allgemeinen fördern zunehmende Lichtintensträten den Prozeß der Verkalkung, wenngleich von einer Sättigungsgrenze an dieser Vorgang cine rückläufige Tendenz aufweist. Eine derartige Beziehung konnte parallel hierzu auch für die Intensität der $\mathrm{C}$-Fixierung und photosynthetischen $\mathrm{O}_{2}$-Produktion festgestellt werden. Diese in situ gewonnenen Ergebnisse wurden durch Laboruntersuchungen bestätigt.
\end{abstract}

\section{IN'TRODUCTION}

Light, by its action on the endosymbiotic algae, is recognized as a primary factor controlling calcification, growth and the distribution of reef-building (hermatypic) corals (Kawaguti \& Sakumoto 1948, Goreau 1963, Barnes 1973, Muscatine 1973). According to the most widely held hypothesis (Goreau 1963), the velocity of the proposed calcification reaction $\left(\mathrm{Ca}^{++}+2 \mathrm{HCO}_{3}-\rightleftharpoons \mathrm{CA}\left(\mathrm{HCO}_{3}\right)_{2} ; \mathrm{Ca}\left(\mathrm{HCO}_{3}\right)_{2} \rightleftharpoons\right.$ $\mathrm{CaCO}_{3}+\mathrm{H}_{2} \mathrm{CO}_{3}$ ) is increased by the photosynthetic fixation of $\mathrm{CO}_{2}$ at or near the calcification site. The validity of this hypothesis has been questioned (e. g. Muscatrine 1973). Nevertheless, photosynthesis is clearly implicated as the driving force behind the high intrinsic rates of calcification in hermatypic corals - regardless of the precise working model. This has been reaffirmed in recent studies of carbon translocation and calcification in the Atlantic coral Acropora cervicornis (Pearse \& Muscatine 1971), and through the use of photosynthetic inhibitors in studies of calcification in the Pacific species Pocillopora damicornis (VANDERmeulen et al. 1972).

Rates of calcification and growth may be profoundly affected by prevailing light intensities at various depths on the reef. GoREAU (1963) suggests that as light decreases, calcification also decreases. He offers this as a possible explanation for the overall 
change in growth form exhibited by the major frame-building corals on Jamaican reefs. Similar phenomena have been discussed by BARNes (1973), in his review of growth, calcification and resulting skeletal form. Precise data on the effect of varying light intensity in situ, and the influence which this has on rates of photosynthetic $\mathrm{CO}_{2}$ fixation, calcification and growth is presently lacking. Its acquisition would add much to a proper assessment of the relationships between light, photosynthesis and calcification in hermatypic corals. The present study is intended to provide some preliminary information in this area through an examination of Montastrea annularis ELLIS \& SOLANDER, one of the major frame-building corals in western Atlantic Ocean reefs and a species showing wide vertical distribution.

\section{MATERIALS AND METHODS}

Work reported here was carried out at experimental sites located on Dancing Lady Reef, Discovery Bay, Jamaica, and Long Reef, Miami (USA). Stations situated at depths of 9, 15, 24.5 and 33.5 meters were selected at each site, and used throughout the study. Specimens of $M$. annularis taken at these depths for experimental use were selected only from populations of the unpigmented growth form (brown due to the presence of algal symbionts), in order to ensure that reasonable comparisons could be made without confusion between physiological races (cf. TAYLOR 1973).

Light intensities were measured at the surface; at the experimental depth and inside each screened compartment of the experimental frame at that depth (see below), using a Gossen Luna Pro Exposure Meter enclosed in a watertight housing. Meter values for incident light readings were converted to footcandles using the scale provided by the manufacturer.

Measurements of $\mathrm{O}_{2}$ production by $M$. annularis (collected at 15 meters) at various light intensities, were obtained in the laboratory using a Clark-type polarographic electrode manufactured by George Johnson, Baltimore, Maryland. A recirculating flow-type chamber, of the same design described by TAYLor (1971), was used throughout. The methods employed were identical (TAYLOR 1971). High intensity, white light was provided by a Xenon arc lamp placed 1 meter from the chamber. Changes in light intensity were obtained through the use of graded neutral density filters. Resulting light values were measured with the same meter described above. Parallel studies of ${ }^{14} \mathrm{CO}_{2}$ fixation during photosynthesis were also performed in the same system using $1 \mu \mathrm{Ci} / \mathrm{ml} \mathrm{NaH}^{14} \mathrm{CO}_{3}$ and the same incubation times.

In situ studies of calcification and carbon fixation were carried out using an experimental frame built in the form of a triangular prism-shaped tent, and constructed from iron reinforcing rod. This was carried to each depth as required. It was divided into three compartments, one dark chamber covered in black polyethylene (a), one chamber shaded with two diagonally crossed layers of fiberglass window screen. (b), and one chamber shaded with one layer of fiberglass window screen (c). A hook was placed in the top of each chamber to hold the experimental bags, and an extension of the apex rod beyond the three chambers was used for the fourth bag in ambient light (d). Light readings showed that illumination in (b) was $1 / 8$ ambient light and illumination in (c) was $1 / 4$ ambient light. Experimental corals measuring $5-10 \mathrm{~cm}$ 
in diameter were carefully removed from the reef. One each was placed in clear polyethylene bags prepared previously by affixing a rubber patch with contact cement for use as an injection port. These were tied off at predetermined points (to ensure that reasonably consistent volumes of water were enclosed in the bag), and the appropriate radioactive label was injected by syringe into the bag using the rubber injection port. After thorough mixing, a sample of labelled seawater from the bag was withdrawn for determination of final activity/ $\mathrm{ml}$ seawater, and the bags were hung from their appropriate hooks on the frame. After 24 hours the experiment was terminated and the corals were collected for analysis.

Rates of ${ }^{14} \mathrm{CO}_{2}$ fixation by $M$. annularis at different light intensities were determined in situ using the experimental frame at depths of 9 and 15 meters. Only ambient light intensities with dark controls were studied at 24.5 and 33.5 meters. Initially, $60 \mu \mathrm{Ci} \mathrm{NaH}{ }^{14} \mathrm{CO}_{3}$ (specific activity: $10 \mu \mathrm{Ci} / 100 \mu \mathrm{g} \mathrm{C}$ ) was injected into each bag. After mixing and sampling, the final concentration was found to be between 0.05 to $0.06 \mu \mathrm{Ci} / \mathrm{ml}$ seawater. Experiments were terminated after 24 hours. Sampling and final counting of labelled corals followed the method given by Cooksey \& Cooksey (1972). The $70 \%$ ethanol and $6 \mathrm{~N} \mathrm{NH}_{4} \mathrm{OH}$ extracts were combined and only total acid stable counts in the coral tissue are reported here.

Rates of calcification were determined at all depths using the experimental frame. Each bag was initially injected with $80 \mu \mathrm{Ci}{ }^{45} \mathrm{CaCl}_{2}$ (specific activity $20 \mu \mathrm{Ci} / \mu \mathrm{g}$ $\mathrm{Ca}$ ). After mixing and sampling, the final concentration ranged between 0.07-0.08 $\mu$ $\mathrm{Ci} / \mathrm{ml}$ seawater. At the termination of each experiment ( 24 hours), the corals were rinsed with seawater and the tissue removed from the skeleton by soaking overnight in a solution of "Clorox" bleach diluted 50:50 with tapwater. Corals were then rinsed thoroughly in tapwater, and rectangular samples were cut from the coral surface using a surgical bone saw. Specimens from shallow stations $(9,15$ meters) exhibit a rounded or dome-shaped growth form, indicating a relatively uniform growth over the surface of the dome. Samples were taken from these in regions near the top of the dome. Deeper specimens (24.5 and 33.5 meters) have a flat, plate-like growth form, indicating greater growth at the edge than at the center of the plate. In these, samples of the skeletal surface were taken from the plate edge as well as the center. After cutting, samples were dried at $110^{\circ} \mathrm{C}$, their polypary surface area determined and weights in air and water obtained for the calculation of skeletal density. Following this, the entire piece was dissolved in $2 \mathrm{ml}$ concentrated $\mathrm{HCl}$, the $\mathrm{pH}$ adjusted to 7.0 with $5 \mathrm{~N} \mathrm{NaOH}$ and the final volume adjusted to $5 \mathrm{ml}$ with distilled water. Aliquots were then plated out on planchets and counted at infinite thinness. Efficiency of counting was determined using a standard sample taken from the original ${ }^{45} \mathrm{CaCl}_{2}$ label.

\section{RESULTS}

Results of laboratory studies of photosynthetic $\mathrm{O}_{2}$ production and $\mathrm{CO}_{2}$ fixation by $M$. annularis are shown graphically in Figure 1 . These observations are comparable to the results of similar studies involving different invertebrate hosts and symbiotic algae (TAYLOR 1971, NOZAWA et al. 1972). Oxygen production and $\mathrm{CO}_{2}$ 
fixation increase in proportion to increasing light intensity until saturating light values are reached at or near 500-600 footcandles. At this point, their respective rates reach a maximum which does not increase appreciably. Comparable results for $\mathrm{CO}_{2}$ fixation have also been obtained in situ (Table 1). These data show that during periods of peak illumination, saturating intensities are reached at depths of 9 and 15 meters on the reefs in Jamaica and Miami. Records of surface illumination throughout the day

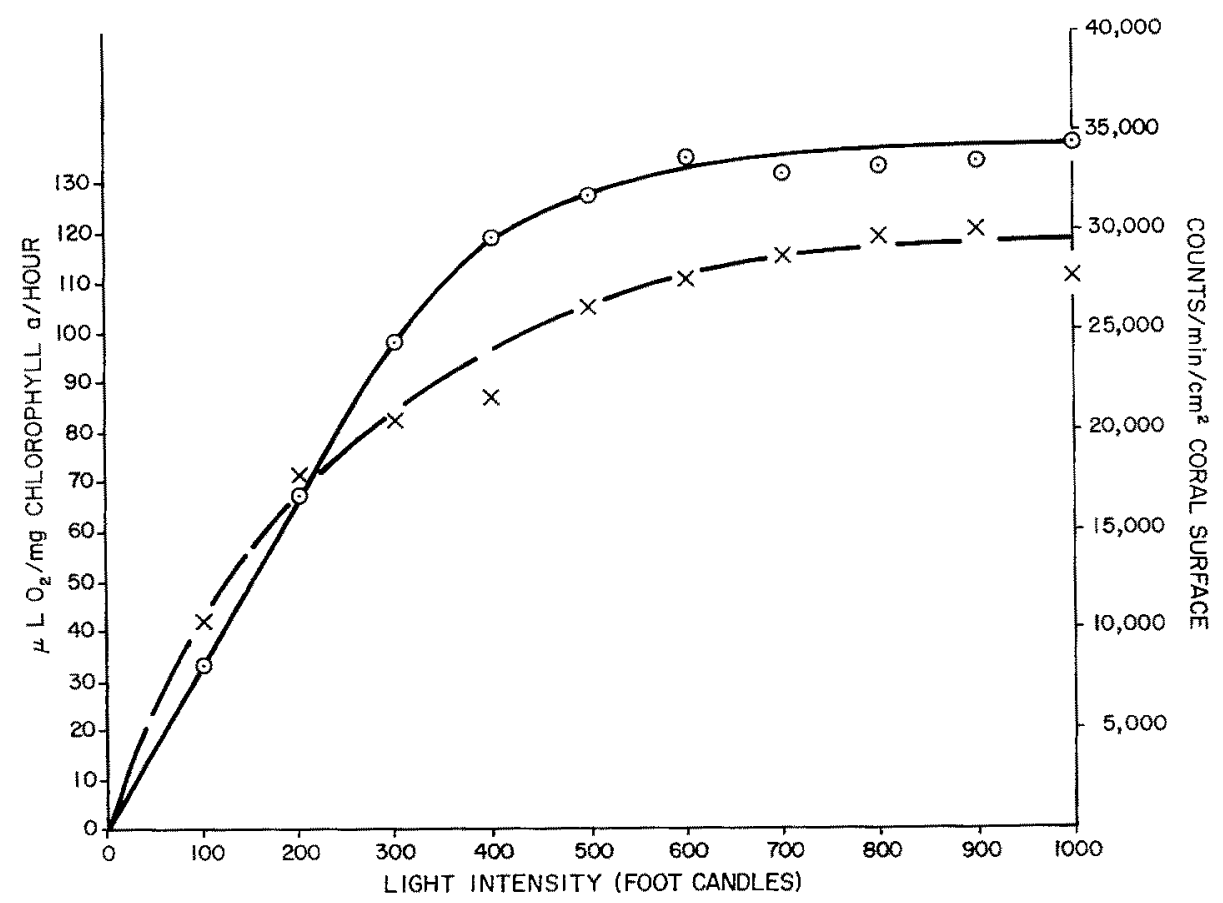

Fig. 1: Photosyathetic $\mathrm{O}_{2}$ production $(x)$ and $\mathrm{CO}_{2}$ fixation $(\odot)$ by the coral Montastrea annularis in vitro

at both sites suggest that peak intensities ( 8000 footcandles) are reached at about 09:00 hours and do not begin to decline until approximately 15:00 hours. Light saturation of the host-symbiont complex would therefore appear to be the prevailing condition at these depths during most of the day.

The data obtained from experiments on in situ calcification rates are presented in Table 2. Specimens of $M$. annularis collected at 9 meters and incubated at this same depth, show an increase in the rate of calcium uptake as available light is increased in the screened portions of the experimental frame. However, when light intensity is above saturating levels (d), the rate of uptake is suppressed to levels similar to those obtained in the most shaded compartment (b). When corals collected at 9 meters are incubated at 33.5 meters, a progressive increase in calcification rate is observed as light levels are increased. The peak light intensity at 33.5 meters was equivalent to the light in the most shaded compartment (b) at 9 meters. Similar rates 
D. J. Barnes \& D. L. Taylor

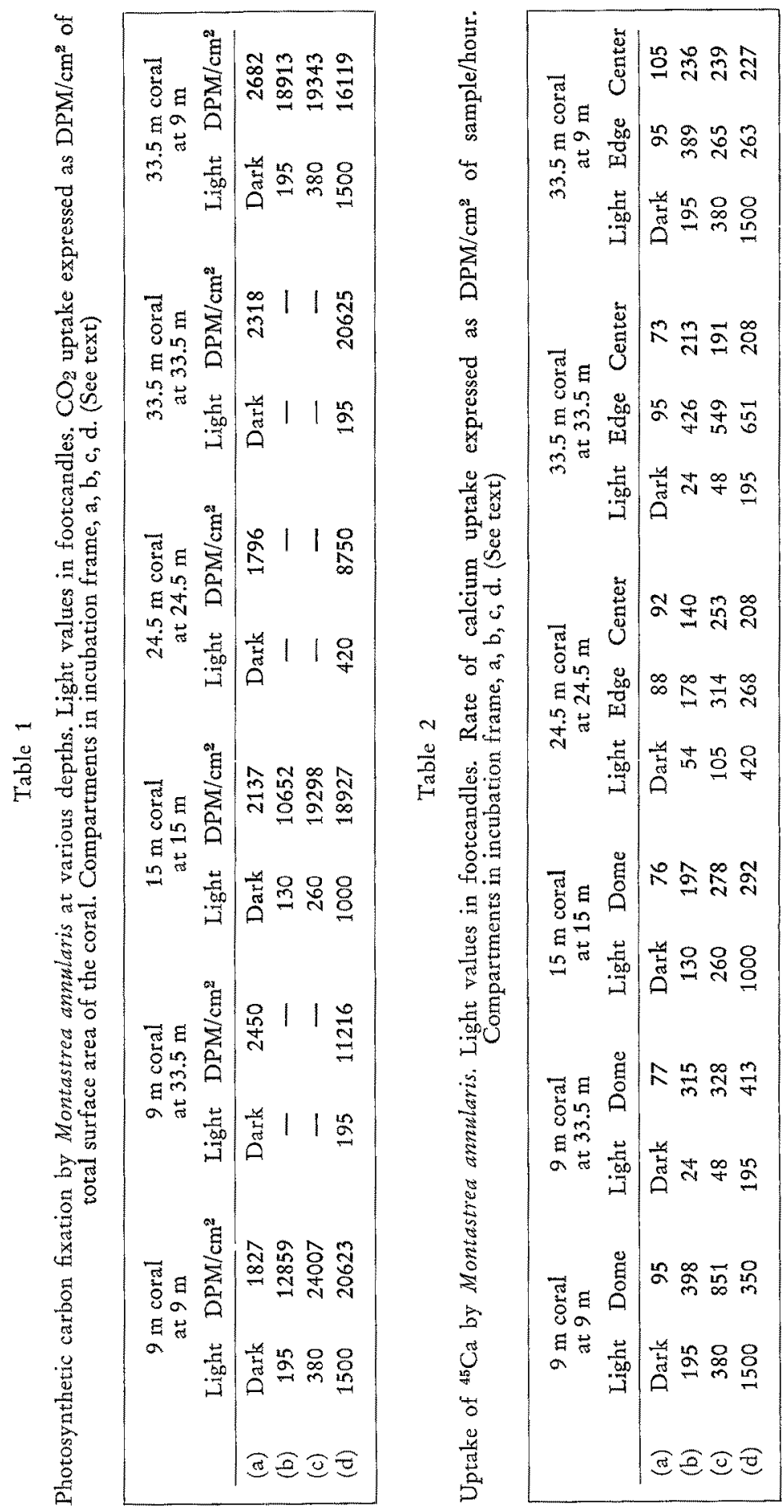


of calcium uptake are observed. The same trends are also found at 15 meters. Saturating intensities occur in (d), and some suppression of calcium uptake is seen. 'This is not as obvious as that found at 9 meters, and the overall rates of calcium uptake are lower. This may be due simply to lower light intensities (cf. specimens at 33.5 meters). Samples from the edge and center of corals collected and incubated at 24.5 meters, have similar rates of calcium uptake and are much the same as those obtained from corals at 15 meters. Near saturating intensities occur in (d) and some reduction in calcification can be seen. Rates are similar to the 15 meter levels, and are less overall than the 9 meter levels. Samples at the edge of corals collected and incubated at 33.5 meters show a progressive increase in the rate of calcification as light is increased. Saturating intensities are not reached at this depth, and there is no suppression of rates at full illumination (d). Unlike corals from 24.5 meters, the rate of calcium uptake at the edge of 33.5 meter specimens is comparably high at all light levels. In contrast, samples taken from the center of these specimens show lower rates of uptake and are generally similar to those obtained at 15 and 24.5 meters. Specimens collected at 33.5 meters and incubated at 9 meters do poorly in comparison with those incubated at 33.5 meters. Samples from the edge of these corals show the best rate of uptake under the light intensities found in compartment (b) of the frame. These light levels are equivalent to the ambient (d) levels recorded at 33.5 meters and uptake rates are similar. Samples from the centers of these corals exhibit the same rates as those from corals incubated at the 33.5 meter depth, and do not appear to be affected by the higher light intensities at 9 meters.

\section{DISCUSSION}

The photosynthetic inhibitors, DCMU (3-[3,4-dichlorophenyl]-1,1-dimethylurea) and CMU (3-[4'-chlorophenyl]-1,1-dimethyl urea), clearly demonstrate an intimate bond between photosynthesis by algal symbionts and the high rates of calcium deposition found in their coral hosts (VANDERMEULEN et al. 1972). Our own study further emphasizes this bond, and illustrates the profound effect which light intensity can have on rates of calcification and photosynthetic carbon fixation in a hermatypic coral.

Inhibition of calcification rates under saturating light intensities is of special interest and deserves further study, particularly with regard to the translocation of energy and materials. As a widespread phenomenon among other major reef-building corals, it could have a profound effect on the overall zonation of the reef, as well as its gross morphology in shallower regions (i. e. down to 15 meters). Fractionation of stable isotopes in the coral skeleton might also be effected by light inhibition, making interpretation of this data more complex than previously supposed (WEBER \& WoODHEAD 1970). Certainly the biological processes involved must be considered carefully. The relationship between photosynthesis and calcification seems to be more intimate than that suggested by the chemical equilibrium discussed above. For this reason, it may be useful to consider light-enhanced calcification in reef-building corals as an energy-requiring process, involving active transport of calcium and carbonate ions, and the translocation of symbiont photosynthate to the faster-growing regions of the 
skeleton. Symbiont photosynthesis would then serve to satisfy basic energy demands, and its interruption by darkness or chemical inhibition would effectively block established transport mechanisms.

At light intensities below saturation, rates of calcification show a general decline as illumination is reduced. However, corals collected and incubated at 33.5 meters exhibit much higher rates than those from 15 and 24.5 meters. We have encountered this same phenomenon in previous, unpublished work on the reefs off Discovery Bay, and find that corals from the deeper stations consistently perform better than those from the middle depths.

Consideration of the form and pattern of growth throughout the colony is useful in interpreting these observations. Overall skeletal growth form relates to the amount of tissue present, and the rate at which this is able to grow and produce new skeleton. The details of this relationship are discussed by BARNEs (1973). Dome-shaped specimens of $M$. annularis collected at 9 and 15 meters result from uniform rates of growth over the entire polypary surface (p. 286). Specimens collected at 24.5 meters are flatter than those from the shallower stations; but they still exhibit a rounded morphology, indicating similar, generalized growth patterns. In contrast, growth in the flat plates collected at 33.5 meters is localized, being concentrated principally at the edge. Similarly, examination of skeletal densities in selected areas of the colony shows an average density of 2.0 at the edge of plates and 2.4 at the center (density of pure $\mathrm{CaCO}_{3}$ [calcite $]=2.7$, confirming that growth is greater at the edge and yields a lighter skeleton. By comparison, the density of shallow water forms is 2.0 overall.

If calcification were dependent on a chemical equilibrium, as postulated previously (GOREAU 1963), these results would not occur, and growth would appear uniform over the colony surface regardless of its morphology. The observation that this is not the case reinforces the view that light-enhanced calcification is an energy requiring process. Under these circumstances, enhanced growth at the edge of plate-like forms is a reflection of the fact that the energy input of algal symbionts is directed, via active transport and carbon translocation, at specific zones of calcification and growth located on the edge of the colony. A similar system has been postulated for Acropora (PEARSE \& MUSCATINE 1971), although the interpretation differs. The apparent rate of calcification and growth in domed forms is lower/unit area, because the energy input of algal symbionts is distributed uniformly over the entire growing surface.

Enhanced outward growth of the plate-like form in deeper water would be a valuable asset in the competition for light and space on the deep reef slope. This, in combination with the high rates of calcification and growth exhibited by the deep corals ( 33.5 meters) studied here, would also serve to explain the overall morphology and outward growing character of the lower reef.

\section{SUMMARY}

1. The effect of varying light intensities on the rates of calcification and $\mathrm{CO}_{2}$ fixation in the coral Montastrea annularis is described. 
2. High light intensities, above the saturation point of symbiont photosynthesis, are shown to inhibit the rate of calcification in both shallow and deep specimens.

3. Light enhanced calcification in reef-building corals appears to be an energy-requiring process involving the active transport of calcium and carbonate ions, and the translocation of symbiont photosynthate.

Acknowledgements. This work was supported by a NATO Post-doctoral Fellowship administered by the Science Research Council of the United Kingdom (DJB), and grants from the Browne Fund of the Royal Society (DLT) and the National Science Foundation (GB-19 790 and GA-25 440) (DLT). The authors are grateful to the Director of the Discovery Bay Marine Laboratory for facilities there. This paper is contribution No. 1579 from Rosenstiel School of Marine and Atmospheric Science, Miami.

\section{LITERATURE CITED}

BARnes, D. J., 1973. Growth in colonial scleractinians. In: Goreau Memorial Volume. Univ. Miami Press, Coral Gables (In press).

COOKSEY, K. E. \& COOKSEY, B., 1972. Turnover of photosynthetically fixed carbon in reef corals Mar. Biol. 15, 289-292.

GOREAU, T. F., 1963. Calcium carbonate deposition by coralline algae and corals in relation to their roles as reef builders. Ann. N. Y. Acad. Sci. 109, 127-167.

Kawagutr, S. \& Sakumoto, D., 1948. The effect of light on the calcium deposition of corals. Bull. oceanogr. Inst. Taiwan 4, 65-69.

Muscatine, L., 1973. Nutrition of Corals. In: Biology of Coral Reefs. Ed. by R. Endean. Acad. Press, New York 2 (in press).

Nozawa, K., Taylor, D. L. \& Provasolt, L., 1972. Respiration and photosynthesis in Convoluta roscoffensis Graff, infected with various symbionts. Biol. Bull. mar. biol. Lab., Woods Hole 143, 420-430.

Pearse, V. B. \& Muscatine, L., 1971. Role of symbiotic algae (zooxanthellae) in coral calcification. Biol. Bull. mar. biol. Lab., Woods Hole 141, 350-363.

TAylor, D. L., 1971. On the symbiosis between Ampbidinium klebsii (Dinophyceae) and Amphiscolops langerhansi (Turbellaria: Acoela). J. mar. biol. Ass., U.K. 51, 301-313.

- 1973. The cellular interactions of algal-invertebrate symbiosis. Adv. mar. Biol. (In press).

Vandermeulen, J. H., Davis, N. D. \& Muscatine, L., 1972. The effect of inhibitors of photosynthesis on zooxanthellae in corals and other marine invertebrates. Mar. Biol. 16, 185-191.

WEBER, J. N. \& WOOdHEAD, P., 1970. Carbon and oxygen isotope fractionation in the skeletal carbonate of reef-building corals. Chem. Geol. 6, 93-123.

First author's address: Dr. D. J. BARNES

UWI-SUNY Marine Laboratory

Discovery Bay

Jamaica 